\title{
Studies of the carcinogenesis and tumorigenesis of skin applications of dodecylbenzene on hairless mice
}

\author{
O H IVERSEN
}

From the Institute of Pathology, University of Oslo, and Department of Laboratory Animals, The National Hospital (Rikshospitalet), N-0027 Oslo 1, Norway

ABSTRACT Dodecylbenzene in various concentrations, dissolved in acetone to a final volume of $50 \mu \mathrm{l}$, was applied twice a week for 78 weeks to the back skin of hairless mice, with or without pretreatment with $51 \cdot 2 \mu \mathrm{g}$ 9,10-dimethyl-1,2-benzanthracene (DMBA). A negative control group was painted with acetone only and a positive control group was given a single application of $51 \cdot 2 \mu \mathrm{g}$ DMBA. A few tumours developed but there was no significant skin tumorigenicity-that is, occurrence of benign or malignant tumours-by acetone alone, or by $16 \%$ dodecylbenzene. More tumours developed in the group treated with $80 \%$ dodecylbenzene than in the group treated with acetone alone or with $16 \%$ dodecylbenzene, but there was no significant difference between treatments with $16 \%$ and $80 \%$ dodecylbenzene. There was only a suggestive increase in tumorigenesis in the group given $51 \cdot 2 \mu \mathrm{g}$ DMBA and thereafter painted with $40 \%$ dodecylbenzene twice a week compared with the group given 51.2 $\mu \mathrm{g}$ DMBA once. As regards histologically malignant tumoursthat is, carcinogenicity - the group treated twice a week with $16 \%$ dodecylbenzene alone developed two skin malignancies, whereas only one carcinoma was observed in the group treated with $80 \%$ dodecylbenzene; both results are non-significant. There was only a suggestive increase in the occurrence of skin malignancies in the group treated with DMBA followed by $40 \%$ dodecylbenzene compared with that treated with DMBA alone. As regards other tumours, treatment with $80 \%$ dodecylbenzene led to six lymphomas in 56 animals, whereas the acetone control group had two lymphomas in 56 animals, a difference which is only suggestive. DMBA alone and DMBA followed by dodecylbenzene gave five and four lymphomas, respectively. There was no significant difference between controls and dodecylbenzene painted animals for lung adenomas or other tumours. A pronounced epidermal hyperplasia, an increase in melanin pigment ("blue spots"), pigment leakage, and skin ulcerations were seen, mainly after $80 \%$ dodecylbenzene and after DMBA followed by $40 \%$ dodecylbenzene. There was an obvious increase in amyloidosis after continual treatment with $80 \%$ dodecylbenzene. The results indicate that $80 \%$ dodecylbenzene alone is weakly tumorigenic but not carcinogenic in the skin of hairless mice, and it tends slightly to enhance DMBA initiated tumorigenesis and carcinogenesis. Dodecylbenzene may be a weak inducer of malignant lymphomas. It is a fairly strong skin irritant and may increase amyloidosis.

Dodecylbenzene is an alkylbenzene manufactured from benzene and alkenes. Alkylbenzenes are used as raw material for sulphonate detergents, as plastisisers for polyvinyl chloride floor covering, and as dielectric fluids. It is an important component of low viscosity cable fluids and is widely used as insulating cable oil. ${ }^{1}$ Since it is used as an insulating fluid in cables in the oil industry in Norway, and since some workers may

Accepted 18 October 1988 occasionally be heavily exposed, it was considered of interest to determine the possible skin carcinogenicity of a particular dodecylbenzene produced by Essochem. A complete toxicological investigation was not intended.

The study was originally directed only at determining the frequency and type of skin tumours. Amyloidosis, signs of skin irritation, and swelling of lymph nodes, however, often became so obvious that we began to record them. Other tumours and lesions in lungs, liver, spleen, and kidneys were occasionally found and registered. 


\section{Materials and methods}

Male and female mice of the $h r / h r$ Oslo strain, obtained from Gamle Bomholt Gaard, Aarhus, Denmark, were used. Spontaneous skin tumours have not been observed in these animals (personal experience). They are known to react normally to the classic two stage treatment protocol for production of skin tumours. ${ }^{2}$ The animals were $60-90$ days old at the beginning of the experiments and weighed $20-25 \mathrm{~g}$. All the mice were housed in plastic cages, eight in each box, using dust free, sterilised wood shavings as bedding. The room had a constant temperature $\left(25^{\circ} \mathrm{C}\right), 50 \%$ humidity, and a $12 / 12 \mathrm{~h}$ light/darkness rhythm. The mice were fed a standard diet (pellets from Felleskjøpet $\mathbf{A} / \mathrm{S}$ ) with free access to water. The cages were cleaned at noon once a week. All the experimental animals, including the negative controls, were kept in the same room. The animals were individually identified by a system of ear and tail markings when they developed a lesion.

\section{CHEMICALS}

The acetone used was of reagent grade. The dodecylbenzene was a $\mathrm{C10}-\mathrm{C} 15$ (predominantly $\mathrm{C12}$ ) branched chain alkyl benzene, and provided by Exxon Chem, Belgium, identification No MRDE-7. This product is a complex mixture of many different isomers of $\mathrm{Cl} 10-\mathrm{Cl} 5$ branched alkylbenzene and it is not possible to provide either purity or formulas. No impurities of toxicological significance are expected to be in the product-for instance, benzene will not be present in view of boiling range of $270-305^{\circ} \mathrm{C}$. It is a clear liquid and its boiling range was $270-305^{\circ} \mathrm{C}$, specific gravity $0.869\left(20 / 20^{\circ} \mathrm{C}\right)$, viscosity $11 \mathrm{cSt}$ at $20^{\circ} \mathrm{C}$, and vapour pressure $0.001 \mathrm{KPa}$ at $20^{\circ} \mathrm{C}$. The 7,12-dimethylbenz(a)anthracene (DMBA) was from Sigma Chemical Company, St Louis, Mo, USA, and was used as purchased.

\section{TUMOUR INDUCTION EXPERIMENTS}

Topical skin applications were made with a graded pipette on the skin of the middle of the back in a final volume of $50 \mu \mathrm{l}$ of either reagent grade acetone, acetone/dodecylbenzene, or DMBA in acetone. Applications were done twice a week for the whole experimental period (80 weeks). Under such circumstances, possible small dose variations at each application are obviously negligible and of no importance for the overall results. Separate pipette tips were used for acetone, dodecylbenzene, and DMBA.

A negative control group (group 1) of 56 mice, 28 males/28 females, was exposed to $50 \mu$ l reagent grade acetone twice a week. An experimental group (2) of 56 mice was given $16 \%$, and a third group (3) of 56 mice received $80 \%$ dodecylbenzene in acetone twice a week.
These groups each contained 56 mice because few tumours or none at all were expected to occur.

A positive control group (4) of 48 mice, 24 males/24 females, was given a single application of $51.2 \mu \mathrm{g}$ DMBA in $50 \mu \mathrm{l}$ acetone and thereafter no treatment. All the animals exposed to a single application of $51.2 \mu \mathrm{g} \mathrm{DMBA}$ at this institute during the past three years (128 mice) represented a fifth, historical control group (5) which was only used in the statistical analysis. A sixth group (6) of 48 mice received $51 \cdot 2 \mu \mathrm{g}$ DMBA in acetone and after one week was painted with $40 \%$ dodecylbenzene in acetone twice a week.

OBSER VATION OF SKIN PAPILLOMAS, SKIN

CANCERS, OTHER TUMOURS, AND CERTAIN

OTHER LESIONS

The animals were examined once a week for 78 weeks. A drawing of each animal was made and each tumour or lesion charted on the drawing. Each tumour was registered as a tumour when it measured more than $1 \mathrm{~mm}^{3}$, and was present for more than two observations. As usual, some animals died during the experiment and others were killed when an obvious malignant skin tumour had appeared. The remaining animals were killed after 78-80 weeks. Whenever possible - that is, except when precluded by extensive autolysis-a necropsy was performed and sections were taken from all the skin lesions, from the lungs, the kidneys, the spleen, the liver, and from enlarged lymph nodes. All tumours registered as malignant were thus histologically verified. Cellular atypia and infiltration below the musculus panniculus was used as a criterion of malignancy for skin tumours. The histological investigations were performed by the author.

The term skin tumorigenesis covers all the skin tumours (papillomas, keratoachantomas, carcinomas, and possible sarcomas). The development of malignant skin tumours (carcinomas and sarcomas) according to histological criteria is called skin carcinogenesis. Spindle cell squamous cell carcinomas are known to occur $^{3}$ and are difficult to distinguish from dermal sarcomas with routine histology. Hence, these are grouped together. Most, if not all of them, are probably spindle cell carcinomas.

\section{STATISTICAL EVALUATION}

On the basis of the crude incidence of skin tumours, elaborate statistical calculations were made according to the recommendations of the IARC. ${ }^{4}$ The results are illustrated as tumour rates (the percentage of tumour bearing animals in relation to the number of animals alive at the appearance of the first tumour related to time)-and tumour yields (the cumulative occurrence of all skin tumours related to time) in all groups. To evaluate significant differences in tumour rates, we used the method for non-incidental tumours first 
Table 1 Percentage survival (actual number of surviving mice in parentheses)

\begin{tabular}{|c|c|c|c|c|c|c|c|c|c|c|c|c|c|c|}
\hline \multirow[b]{2}{*}{ Treatment } & \multicolumn{14}{|c|}{ Week } \\
\hline & 0 & 20 & 25 & 30 & 35 & 40 & 45 & 50 & 55 & 60 & 65 & 70 & 75 & 80 \\
\hline 1 Acetone alone & $\begin{array}{l}100 \\
(56)\end{array}$ & $\begin{array}{c}98 \\
(55)\end{array}$ & $\begin{array}{l}98 \\
(55)\end{array}$ & $\begin{array}{l}96 \\
(54)\end{array}$ & $\begin{array}{l}94 \\
(53)\end{array}$ & $\begin{array}{l}92 \\
(52)\end{array}$ & $\begin{array}{l}92 \\
(52)\end{array}$ & $\begin{array}{l}92 \\
(52)\end{array}$ & $\begin{array}{l}90 \\
(50)\end{array}$ & $\begin{array}{l}90 \\
(50)\end{array}$ & $\begin{array}{l}90 \\
(50)\end{array}$ & $\begin{array}{l}90 \\
(50)\end{array}$ & $\begin{array}{l}90 \\
(50)\end{array}$ & $\begin{array}{l}90 \\
(50)\end{array}$ \\
\hline $216 \%$ Dodecylbenzene in acetone & $\begin{array}{l}100 \\
(56)\end{array}$ & $\begin{array}{r}98 \\
(55)\end{array}$ & $\begin{array}{l}98 \\
(55)\end{array}$ & $\begin{array}{l}98 \\
(55)\end{array}$ & $\begin{array}{l}98 \\
(55)\end{array}$ & $\begin{array}{l}96 \\
(54)\end{array}$ & $\begin{array}{l}95 \\
(53)\end{array}$ & $\begin{array}{l}95 \\
(53)\end{array}$ & $\begin{array}{l}95 \\
(53)\end{array}$ & $\begin{array}{l}95 \\
(53)\end{array}$ & $\begin{array}{l}90 \\
(50)\end{array}$ & $\begin{array}{l}90 \\
(50)\end{array}$ & $\begin{array}{l}90 \\
(50)\end{array}$ & $\begin{array}{l}90 \\
(50)\end{array}$ \\
\hline $380 \%$ Dodecylbenzene in acetone & $\begin{array}{l}100 \\
(56)\end{array}$ & $\begin{array}{l}100 \\
(56)\end{array}$ & $\begin{array}{l}98 \\
(55)\end{array}$ & $\begin{array}{l}98 \\
(55)\end{array}$ & $\begin{array}{l}98 \\
(55)\end{array}$ & $\begin{array}{l}96 \\
(54)\end{array}$ & $\begin{array}{l}94 \\
(53)\end{array}$ & $\begin{array}{l}94 \\
(53)\end{array}$ & $\begin{array}{l}94 \\
(53)\end{array}$ & $\begin{array}{l}94 \\
(53)\end{array}$ & $\begin{array}{l}92 \\
(52)\end{array}$ & $\begin{array}{l}92 \\
(52)\end{array}$ & $\begin{array}{l}90 \\
(50)\end{array}$ & $\begin{array}{l}84 \\
(47)\end{array}$ \\
\hline $451 \cdot 2 \mu \mathrm{g}$ DMBA once & $\begin{array}{l}100 \\
(48)\end{array}$ & $\begin{array}{l}100 \\
(48)\end{array}$ & $\begin{array}{l}97 \\
(47)\end{array}$ & $\begin{array}{l}97 \\
(47)\end{array}$ & $\begin{array}{l}97 \\
(47)\end{array}$ & $\begin{array}{l}97 \\
(47)\end{array}$ & $\begin{array}{l}94 \\
(47)\end{array}$ & $\begin{array}{l}94 \\
(45)\end{array}$ & $\begin{array}{l}94 \\
(45)\end{array}$ & $\begin{array}{l}88 \\
(42)\end{array}$ & $\begin{array}{l}85 \\
(41)\end{array}$ & $\begin{array}{l}83 \\
(40)\end{array}$ & $\begin{array}{l}79 \\
(38)\end{array}$ & $\begin{array}{l}73 \\
(35)\end{array}$ \\
\hline $\begin{array}{l}651 \cdot 2 \mu \mathrm{g} \text { DMBA once followed by } \\
40 \% \text { dodecylbenzene }\end{array}$ & $\begin{array}{l}100 \\
(48)\end{array}$ & $\begin{array}{r}98 \\
(47)\end{array}$ & $\begin{array}{l}98 \\
(47)\end{array}$ & $\begin{array}{l}96 \\
(46)\end{array}$ & $\begin{array}{l}96 \\
(46)\end{array}$ & $\begin{array}{l}94 \\
(45)\end{array}$ & $\begin{array}{l}94 \\
(45)\end{array}$ & $\begin{array}{l}90 \\
(43)\end{array}$ & $\begin{array}{l}88 \\
(42)\end{array}$ & $\begin{array}{l}83 \\
(40)\end{array}$ & $\begin{array}{l}79 \\
(38)\end{array}$ & $\begin{array}{l}79 \\
(38)\end{array}$ & $\begin{array}{l}79 \\
(38)\end{array}$ & $\begin{array}{l}79 \\
(38)\end{array}$ \\
\hline
\end{tabular}

described by Peto ${ }^{5}$ and elaborated by a computer based test program by Peto et al. ${ }^{4}$ This program takes into account varying mortality rates between the experimental groups and assesses both the number of tumour bearing animals and the time to the first tumour in each animal.

To evaluate the difference in tumour yields we have used the method of Gail et al based on multiple times to tumour (method 3). ${ }^{6}$ This method assesses the number of tumours appearing, the varying mortality rates between the groups, and the time of appearance of each tumour.

We used the chi-squared test to evaluate the final occurrence of lymphomas and skin cancers.

Statistical significance has been defined as follows: $0.10>\mathrm{p}>0.05=$ suggestive, $0.05>\mathrm{p}>0.01=$ significant, $\quad 0.01>p>0.00=$ very significant. Pronounced biological variations are known to occur in biological skin painting experiments. ${ }^{78}$ Hence, statistical significance is not always the same as biological significance and some small, statistically non-significant differences may still be real.

\section{Results}

\section{SKIN TUMOURS}

The survival in actual numbers and as percentages is presented in table 1, the crude and adjusted (for groups 4 and 6) end results in table 2, and tumour rates and yields in figs 1 and 2 . Statistical evaluations are shown in tables 3 and 4.

To make the results comparable the end results and the curves for tumour yield, for groups 4 and 6 (fig 2), have been adjusted to show the total number of tumours occurring in a group starting with 56 mice. Hence, the values observed for the two groups comprising only 48 mice have been multiplied by $56 /$ $48=1 \cdot 1667$. The values shown in table 2 and fig 2 thus represent the number of tumours that actually appeared in the groups of mice, and those that would have appeared in a group of 56 mice with the same tumour yield as that actually observed in the 48 mice. The final occurrence of skin tumours in table 2 (illustrated with respect to time in figs 1 and 2) shows that the two groups initially painted with $51 \cdot 2 \mu \mathrm{g}$

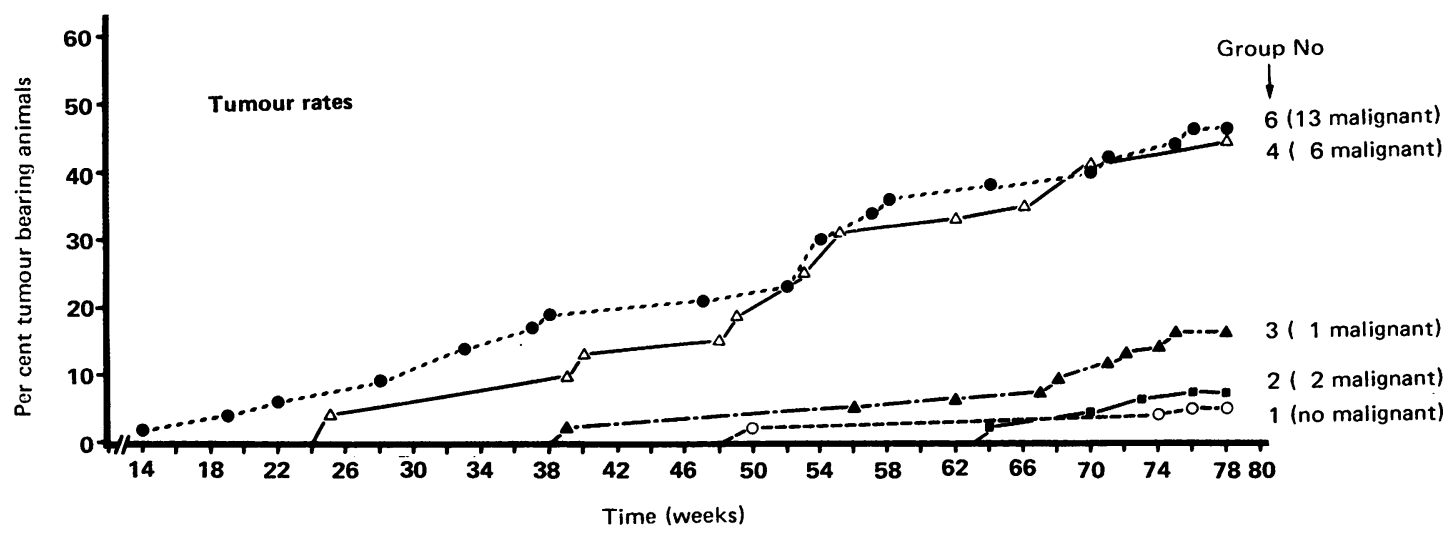

Fig 1 Tumour rate (tumour bearing animals as a percentage of those alive at appearance of first tumour related to time) during observation period for each of five experimental groups. Final number of malignant skin tumours is given in parentheses at end of each curve. For various treatment schedules see text, materials and methods. 
Table 2 Tumorigenicity of dodecylbenzene: tumour analysis and pathological findings

\begin{tabular}{|c|c|c|c|c|c|}
\hline $\begin{array}{l}\text { Group No } \\
\text { No of mice in group } \\
\text { Treatment }\end{array}$ & $\begin{array}{l}l \\
56 \\
\text { Acetone }\end{array}$ & $\begin{array}{l}2 \\
56 \\
\text { Dodecylbenzene } \\
16 \%\end{array}$ & $\begin{array}{l}3 \\
56 \\
80 \%\end{array}$ & $\begin{array}{l}4 \\
48(56) \\
\text { DMBA once }\end{array}$ & $\begin{array}{l}6 \\
48(56) \\
\text { DMBA }+40 \% \\
\text { Dodecylbenzene }\end{array}$ \\
\hline Type of tumour: & \multicolumn{5}{|c|}{ No of tumours (lesions)/No of animals with tumours (lesions) } \\
\hline $\begin{array}{l}\text { Skin tumours: } \\
\text { All skin tumours } \\
\text { Carcinomas } \\
\text { Sarcomas } \\
\text { Skin malignancies }\end{array}$ & $\begin{array}{l}3 / 2^{*} \\
0 \\
0 \\
0\end{array}$ & $\begin{array}{l}4 / 4 \\
1 / 1 \\
1 / 1 \\
2 / 2\end{array}$ & $\begin{array}{l}13 / 9 \\
1 / 1 \\
0 \\
1 / 1\end{array}$ & $\begin{array}{l}53 / 23(62 / 27) \\
5 / 5(6 / 6) \\
0(0) \\
5 / 5(6 / 6)\end{array}$ & $\begin{array}{l}68 / 22(79 / 26) \\
5 / 5(6 / 6) \\
6 / 6(7 / 7) \\
11 / 11(13 / 13)\end{array}$ \\
\hline $\begin{array}{l}\text { Lymphoid tumours: } \\
\text { B-cell lymphoma } \\
\text { Lymphoma NOS }\end{array}$ & $\begin{array}{l}0 \\
2 / 2\end{array}$ & $\begin{array}{l}0 \\
2 / 2\end{array}$ & $\begin{array}{l}0 \\
6 / 6\end{array}$ & $\begin{array}{l}1 / 1(1 / 1) \\
3 / 3(4 / 4)\end{array}$ & $\begin{array}{l}0(0) \\
3 / 3(4 / 4)\end{array}$ \\
\hline $\begin{array}{l}\text { Sum lymphomas: } \\
\text { Reticuloses }\end{array}$ & $\begin{array}{l}2 / 2 \\
3 / 3\end{array}$ & $\begin{array}{l}2 / 2 \\
4 / 4\end{array}$ & $\begin{array}{l}6 / 6 \\
1 / 1\end{array}$ & $\begin{array}{l}4 / 4(5 / 5) \\
2 / 2(2 / 2)\end{array}$ & $\begin{array}{l}3 / 3(4 / 4) \\
2 / 2(2 / 2)\end{array}$ \\
\hline Sum lymphoid lesions: & $5 / 5$ & $6 / 6$ & $7 / 7$ & $6 / 6(7 / 7)$ & $5 / 5(6 / 6)$ \\
\hline $\begin{array}{l}\text { Lung adenomas: } \\
\text { Per cent of all necropsied }\end{array}$ & $\begin{array}{l}4 / 3 \\
10\end{array}$ & $\begin{array}{l}8 / 6 \\
20\end{array}$ & $11^{6 / 6}$ & $\begin{array}{l}14 / 10(16 / 12) \\
27\end{array}$ & $13 / 4(7 / 5)$ \\
\hline $\begin{array}{l}\text { Other tumours: } \\
\text { Abdominal sarcoma } \\
\text { Angiosarcoma of liver } \\
\text { Hepatoma }\end{array}$ & $\begin{array}{l}1 / 1 \\
0 \\
0\end{array}$ & $\begin{array}{l}1 / 1 \\
0 \\
0\end{array}$ & $\begin{array}{l}0 \\
1 / 1 \\
1 / 1\end{array}$ & $\begin{array}{l}0 \\
0 \\
0\end{array}$ & $\begin{array}{l}1 / 1(1 / 1) \\
1 / 1(1 / 1) \\
0\end{array}$ \\
\hline $\begin{array}{l}\text { Amyloidosis: } \\
\text { Per cent of all necropsied }\end{array}$ & $\begin{array}{l}2 / 2 \\
5\end{array}$ & $\begin{array}{l}9 / 9 \\
23\end{array}$ & $\begin{array}{l}22 / 22 \\
39\end{array}$ & $\begin{array}{l}12 / 12(14 / 14) \\
23\end{array}$ & $5 / 5(6 / 6)$ \\
\hline $\begin{array}{l}\text { Skin toxicity: } \\
\text { Pronounced hyperplasia } \\
\text { Ulcerations } \\
\text { Pigment disturbances }\end{array}$ & $\begin{array}{l}0 \\
0 \\
0\end{array}$ & $\begin{array}{l}+ \\
0 \\
+\end{array}$ & $\begin{array}{l}++ \\
+ \\
++\end{array}$ & $\begin{array}{l}0 \\
0 \\
0\end{array}$ & $\begin{array}{l}++ \\
+ \\
+++\end{array}$ \\
\hline
\end{tabular}

Skin tumours, other tumours and some lesions found in hairless mice painted with acetone, DMBA, and dodecylbenzene as indicated. When numbers are given as fractions the numerator indicates number of tumours or lesions observed in groups of 48 or 56 mice (see text), and the denominator indicates number of affected animals. The figures in brackets for groups 4 and 6 are adjustments to 56 mice, for comparison. Group 5 is a historical group used only for statistics and hence not depicted in the table.

*Three very small, entirely benign papillomas.

NOS = No other specification. For more detailed explanation, see text.

DMBA had the highest tumour rates and yields, whereas the three groups with dodecylbenzene in acetone or acetone alone had a low occurrence of tumours. The four upper rows of results in table 1 show the numbers of the various tumours per number of animals with tumours.

Table 3 shows the statistical assessments of skin tumorigenicity. In this table we have not only taken into consideration the specific, positive control group used in this experiment (group 4) but also compared it with another large group comprising 128 mice which had been painted once with $51 \cdot 2 \mu \mathrm{g}$ DMBA at this institute during the past three years (group 5). There were no statistical differences in tumour rates or yields between these two latter experiments (groups 4 and 5 , respectively). The $t$ value for positive trend for tumour bearing animals in this comparison was 1.92 , with a one tailed $p$ value of 0.32 , and the chi squared statistics for heterogeneity gave a $p=0 \cdot 65$. For tumour yield the chi squared was $2.64(0.20>p>0 \cdot 10)$. Hence, the larger group may also be used for statistical comparison with the experimental results of this study.

There was no significant difference between group 1, painted with acetone alone, and group 2, painted with
$16 \%$ dodecylbenzene twice a week, but there was a significant difference between group 1 (acetone) and group 3, painted with $80 \%$ dodecylbenzene, the latter resulting in more skin tumours. There was no significant difference between groups 2 and 3 painted with 16 and $80 \%$ dodecylbenzene, respectively. There was naturally a very significant difference between the acetone painted negative (group 1) and the positive (groups 4 and 5) control groups painted once with $51.2 \mu \mathrm{g} \mathrm{DMBA}$, but there was only a suggestive or non-significant difference between group 4 , painted with $51.2 \mu \mathrm{g}$ DMBA alone, and group 6, painted with DMBA followed by twice weekly applications of $40 \%$ dodecylbenzene. There was, however, a suggestive (for tumour rates) or significant (for tumour yields) difference when group 6, painted with DMBA $+40 \%$ dodecylbenzene, was compared with the large group 5 of historical controls. Hence, there is a slight indication that painting with $40 \%$ dodecylbenzene twice a week for 78 weeks may enhance DMBA induced tumorigenesis.

As regards skin carcinogenesis - that is, the induction of malignant tumours of the skin (table 4) - there was no significant difference between group 1, painted 


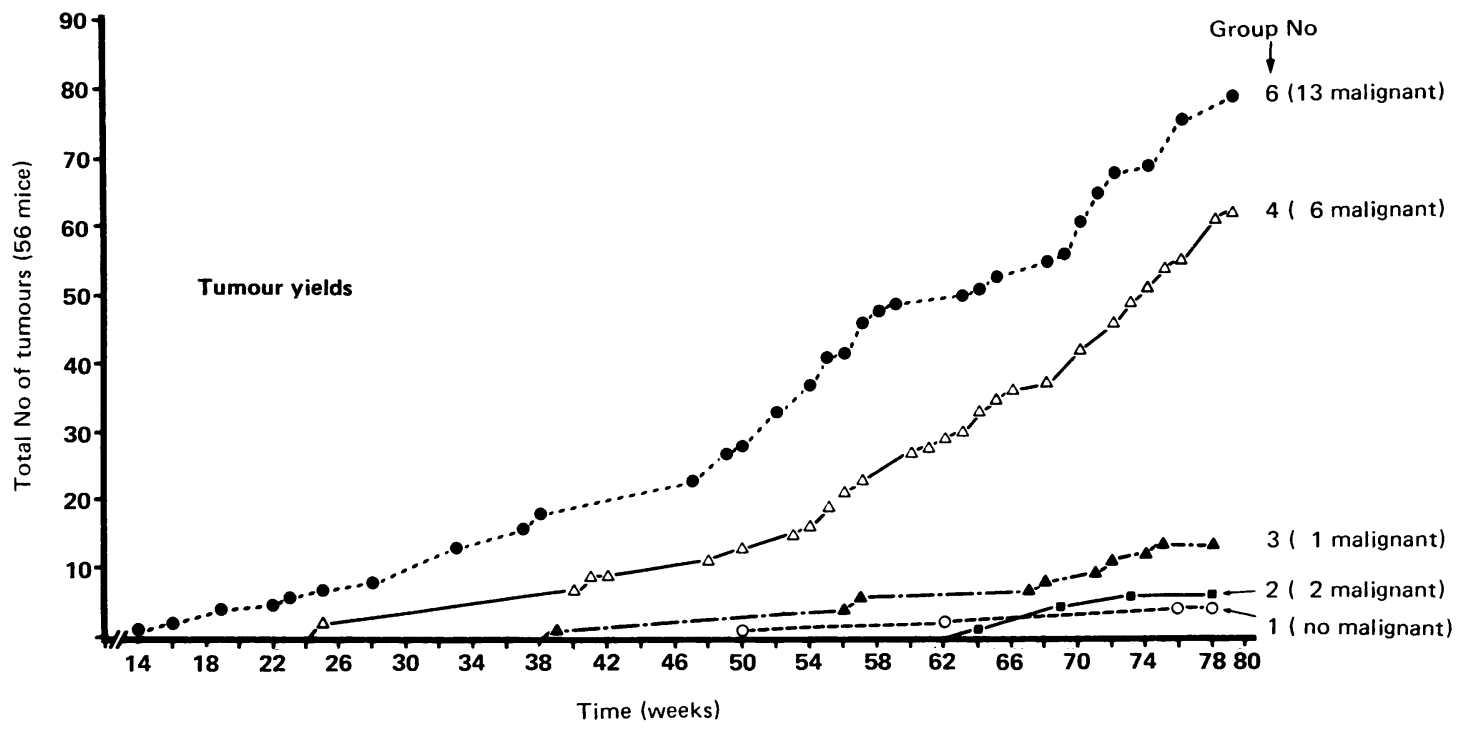

Fig 2 Tumour yield (total number of tumours appearing adjusted to groups of 56 mice related to time) during observation period for five experimental groups. For further explanation, see text to fig 1 .

with acetone alone, and group 2, painted twice a week with $16 \%$ dodecylbenzene. Only one skin malignancy developed in group 3, painted twice a week with $80 \%$ dodecylbenzene, which does not differ significantly from either group 1 or group 2. There was a significant difference between the acetone painted group 1 on the one hand, and group 4, painted with DMBA alone, and between group 1 and group 6, painted with DMBA $+40 \%$ dodecylbenzene. The difference between the groups painted only with DMBA (group 4) and the group given DMBA followed by $40 \%$ dodecylbenzene (group 6) was only suggestive.

Hence, the results show that continual treatment of $h r / h r$ mice twice a week with $80 \%$ dodecylbenzene is a weak skin tumorigen, but not a carcinogen, for hairless mouse skin, whereas $16 \%$ dodecylbenzene alone given twice a week has no significant tumorigenic or carcinogenic potency. DMBA alone given once is confirmed as a tumorigen and a carcinogen. When $40 \%$ dodecylbenzene is given twice a week

Table 3 Statistical analysis of skin tumours

\begin{tabular}{|c|c|c|c|c|c|c|c|c|c|c|}
\hline & \multicolumn{5}{|c|}{ Tumour rates } & \multicolumn{5}{|c|}{ Tumour yields } \\
\hline & $\begin{array}{l}l \vee 3 \\
\text { Obs } / \text { Exp }\end{array}$ & $\begin{array}{l}l v 4 \\
\text { Obs/Exp }\end{array}$ & $\begin{array}{l}l \text { y } 5 \\
\text { Obs/Exp }\end{array}$ & $\begin{array}{l}6 \vee 4 \\
\text { Obs/Exp }\end{array}$ & $\begin{array}{l}6 \vee 5 \\
\text { Obs/Exp }\end{array}$ & $\begin{array}{l}\text { I } v 3 \\
\text { Best odds }\end{array}$ & $\begin{array}{l}l v 4 \\
\text { Best odds }\end{array}$ & $\begin{array}{l}\text { lv } 5 \\
\text { Best odds }\end{array}$ & $\begin{array}{l}6 v 4 \\
\text { Best odds }\end{array}$ & $\begin{array}{l}6 \vee 5 \\
\text { Best ods }\end{array}$ \\
\hline \multirow{2}{*}{$\begin{array}{l}1 \text { Acetone alone } \\
216 \% \text { Dodecylbenzene in acetone } \\
380 \% \text { Dodecylbenzene in acetone }\end{array}$} & $0 \cdot 26$ & 0.08 & 0.06 & & & 1.00 & 0.03 & 0.04 & & \\
\hline & 1.94 & & & & & $\begin{array}{l}8.69 \\
\text { (week 57) }\end{array}$ & & & & \\
\hline \multirow{2}{*}{$\begin{array}{l}451.2 \mu \mathrm{g} \text { DMBA once (this study) } \\
551.2 \mu \mathrm{g} \text { DMBA once (128 mice) } \\
651.2 \mu \mathrm{g} \text { DMBA once followed by } \\
40 \% \text { Dodecylbenzene } \\
T\end{array}$} & & $2 \cdot 39$ & 1.49 & 0.89 & 0.89 & & 1.00 & 1.00 & 1.00 & 1.00 \\
\hline & & & & $1 \cdot 12$ & $1 \cdot 37$ & & & & $\begin{array}{l}1 \cdot 56 \\
\text { (week 38) }\end{array}$ & $\begin{array}{l}1.55 \\
\text { (week } 3\end{array}$ \\
\hline \multirow{4}{*}{$\begin{array}{l}\text { T } \\
\text { One tailed } p \text { value for positive trend } \\
\text { Chi-squared for heterogeneity } \\
\text { Degree of freedom } \\
\text { p Value for heterogeneity } \\
\text { Best } p \text { value for tumour yield }\end{array}$} & $\begin{array}{l}2.91 \\
0.0130\end{array}$ & $\begin{array}{l}11.64 \\
<0.0001\end{array}$ & $\begin{array}{l}15.70 \\
<0.0001\end{array}$ & $\begin{array}{l}2.43 \\
0.2274\end{array}$ & $\begin{array}{l}6 \cdot 18 \\
0 \cdot 0406\end{array}$ & & & & & \\
\hline & $\begin{array}{l}4 \cdot 96 \\
1 \\
0 \cdot 0260\end{array}$ & $\begin{array}{l}29 \cdot 26 \\
1 \\
<0.0001\end{array}$ & $\begin{array}{l}23.97 \\
1 \\
<0.0001\end{array}$ & $\begin{array}{l}0.56 \\
1 \\
0.4547\end{array}$ & $\begin{array}{l}3.04 \\
1 \\
0.0811\end{array}$ & $\begin{array}{l}5 \cdot 45 \\
1\end{array}$ & $\begin{array}{l}28 \cdot 82 \\
1\end{array}$ & $\begin{array}{l}25 \cdot 22 \\
1\end{array}$ & $\begin{array}{l}3 \cdot 34 \\
1\end{array}$ & $\begin{array}{l}4 \cdot 42 \\
1\end{array}$ \\
\hline & & & & & & $\begin{array}{l}0.025> \\
p>0.010\end{array}$ & $<0.0005$ & $<0.0005$ & $\begin{array}{l}0.10> \\
p>0.05\end{array}$ & $\begin{array}{l}0.05> \\
p>0.02\end{array}$ \\
\hline & $\mathbf{s}$ & vs & vs & ns & sugg & s & vs & vs & sugg & $\mathrm{s}$ \\
\hline
\end{tabular}

$\mathrm{s}=$ Significant vs $=$ very significant $; \mathrm{ns}=$ not significant; sugg $=$ suggestive.

For detailed explanation of statistics, see refs $12,13,14$. All other comparisons were not significant. 
Table 4 Chi-squared assessment of lymphomas and malignant skin tumours (one tailed p)

\begin{tabular}{|c|c|c|}
\hline Groups tested & Lymphomas & Malignant skin tumours \\
\hline $1 v 2$ & & $\begin{array}{l}\chi^{2}=2.04, \\
1 \mathrm{DF}, 0 \cdot 20>\mathrm{p}>0 \cdot 10 \\
\text { not significant }\end{array}$ \\
\hline $1 v 3$ & $\begin{array}{l}\chi^{2}=1.88 \\
1 \mathrm{DF}, 0 \cdot 10>\mathrm{p}>0.05 \\
\text { suggestive }\end{array}$ & \\
\hline $1 v 4$ & $\begin{array}{l}x^{2}=1.63, \\
1 \text { DF, } 0.15>p>0.10 \\
\text { non-significant }\end{array}$ & $\begin{array}{l}\chi^{2}=6.78 \\
1 \mathrm{DF}, 0.010>\mathrm{p}>0.005 \\
\text { very significant }\end{array}$ \\
\hline $1 v 6$ & $\begin{array}{l}\chi^{2}=1.08 \\
1 \mathrm{DF}, 0.15>\mathrm{p}>0.10 \\
\text { non-significant }\end{array}$ & $\begin{array}{l}\chi^{2}=13.33 \\
1 \mathrm{DF}, \mathrm{p}>0.005 \\
\text { very significant }\end{array}$ \\
\hline $4 v 6$ & & $\begin{array}{l}\chi^{2}=2 \cdot 13, \\
1 \mathrm{DF}, 0 \cdot 10>\mathrm{p}>0.05 \\
\text { suggestive }\end{array}$ \\
\hline
\end{tabular}

All other differences were non-significant.

for 18 months after a single dose of $51 \cdot 2 \mu \mathrm{g}$ DMBA, it shows only a small, suggestive, but not significant, enhancing activity.

\section{LYMPHOID TUMOURS}

The occurrence of lymphoid tumours is shown in table 2 and the statistical evaluation in table 4 . When there was a diffusely proliferating population of lymphocytes without cellular atypia in lymph nodes, and hence not an obvious malignant lymphoma, the lesion was classified as a reticulosis. We followed Wogan's advice on criteria for the diagnosis of malignant lymphoma or leukaemia in mice. ${ }^{9}$ The collection of plasma cells in the spleen or lymph nodes was registered only as reactive changes and not as plasmacytomas or mature B cell lymphomas. In many of the obvious cases of lymphoma we observed massive infiltrations in the lungs, liver, kidneys, and once even in the heart muscle (fig 3), showing lymphoma involvement of many organs. It may be seen from tables 2 and 4 that treatment with $80 \%$ dodecylbenzene resulted in six lymphomas in a group of 56 mice, whereas the acetone group showed only two lymphomas in 56 animals. This difference, however, is only suggestive with the chi squared test. DMBA alone and DMBA followed by dodecylbenzene gave five and four lymphomas, respectively. If reticuloses were also counted there seemed to be no significant difference in the incidence of lymphoproliferative lesions in any of the treatment schedules. Hence, dodecylbenzene alone may be a weak inducer of malignant lymphomas and DMBA gave no extra effect.

\section{LUNG ADENOMAS}

There was no significant increase in lung adenomas in dodecylbenzene painted animals versus the acetone treated controls. A single application of DMBA alone significantly increased the number of lung adenomas compared with the acetone control group (table 4). A statistically significant further increase, however, was not seen in the treatment group receiving DMBA followed by $40 \%$ dodecylbenzene (table 2 ). Hence, dodecylbenzene did not induce lung adenomas.

\section{OTHER TUMOURS}

A few abdominal sarcomas, one angiosarcoma of the liver, and a hepatoma occurred as seen in table 2 . There was no statistical indication that these were related to dodecylbenzene or DMBA.

\section{TOXIC MANIFESTATIONS}

As regards the degenerative lesion amyloidosis, there was an obvious increase in amyloidosis after treatment twice a week with $80 \%$ dodecylbenzene. This was observed in the spleen, in the kidneys, and in the liver. The explanation for the increase in amyloidosis is not clear, but if it is taken as a sign of general toxicity, painting with $80 \%$ dodecylbenzene twice a week seems to be fairly toxic for the animals. Why this co-variation disappeared when the mice were also treated with DMBA is unknown.

In the skin we recorded ulcerations, pronounced hyperplasia, excess, unevenly distributed pigmentation (pigment leakage and some "blue spots'), and various degrees of chronic dermatitis with many mast cells. The most pronounced hyperplasia and even ulcerations were seen after treatment with $80 \%$ dodecylbenzene, and after DMBA followed by $40 \%$ dodecylbenzene. Hence, the results show that dodecylbenzene displays strong skin toxicity for hairless mice (fig 4) in addition to its weak tumorigenicity.

\section{Discussion}

A review of the physicochemical and toxicological aspects of dodecylbenzenes has been published by Rönneberg.' His review (containing detailed references) documents that dodecylbenzene may be absorbed through the skin, the lungs, and the gastrointestinal tract. Significant amounts of dodecylbenzene are still not metabolised after 24 hours. Absorption, distribution, biotransformation, and elimination have not been studied quantitatively. Dodecylbenzene has low acute toxicity by the oral route. $\mathrm{LD}_{50}$ for rodents has been reported to be $2000-3000 \mathrm{mg}$ per $100 \mathrm{~g}$ weight. ${ }^{10}$ "Inhalation toxicity appears to be higher.'

Dodecylbenzene is a skin irritant, and even a single application may lead to an inflammatory reaction and transient hyperplasia and hyperkeratosis in mouse skin. Repeated surface applications may induce severe skin irritation and even ulceration in rodents. ${ }^{12}$ Other organs are also affected, such as the respiratory tract, lungs, kidneys, blood and haemopoietic tissue, and the 


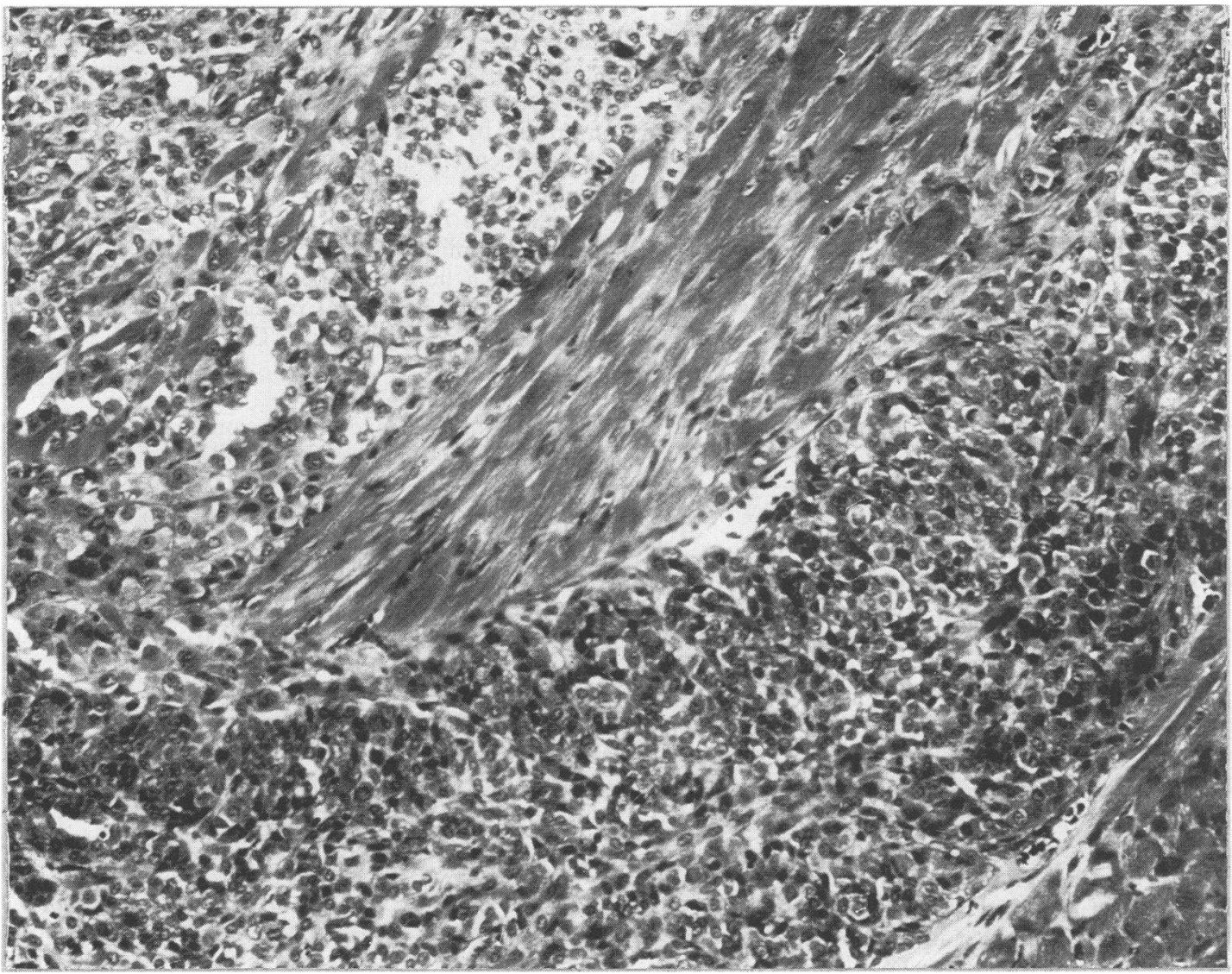

Fig 3 Photomicrograph of massive infiltration of heart muscle by malignant lymphoma cells in a mouse belonging to group 6. (Initial magnification $320 \times$.)

central nervous system. ${ }^{\prime}$ Chronic dodecylbenzene exposure has been implicated as a cause of thymus atrophy, possibly leading to an impaired immunological defence. ${ }^{13}$ There is no evidence, however, of allergic reactions of skin or respiratory tract. ${ }^{9}$ The evidence on putative genotoxicity is inadequate. ${ }^{14}$ The possible genotoxicity of three linear alkylbenzenes have been tested with the Ames test, in vivo bone marrow chromosome studies, and the Chinese hamster ovary cell test. All test results were completely negative (personal communication J S Harding, Monsanto Europe, Brussels).

When applied to the skin some is absorbed through this organ and some perorally since the animals frequently lick themselves and one another.

Some skin tumours have been reported to develop in mouse skin painting assays, but none of the earlier studies has included negative solvent treated controls. ${ }^{12}{ }^{16}$ It has been discussed whether the tumorigen- icity is due to contamination with polycyclic aromatic hydrocarbons. ${ }^{1216}$ There are also a few indications about possible increase in the incidence of lymphomas in alkylbenzene treated animals. ${ }^{17}$

In studies of tumour production in mice after skin painting there are always large biological variations in the results between similar experiments performed with the same strain of mice at different times, and sometimes even between the various cages in the same experiment, as mentioned above. ${ }^{78}$ Some of the differences presented here are formally significant and some are only suggestive. A cautionary note has to be struck since there is still a possibility that significant differences may be due to "an unlucky hit" based on large, but random biological variations.

It is always difficult to assess the significance of results from animal experiments for human tumorigenesis and carcinogenesis. Generally, man is more resistant than mouse to chemical carcinogens 


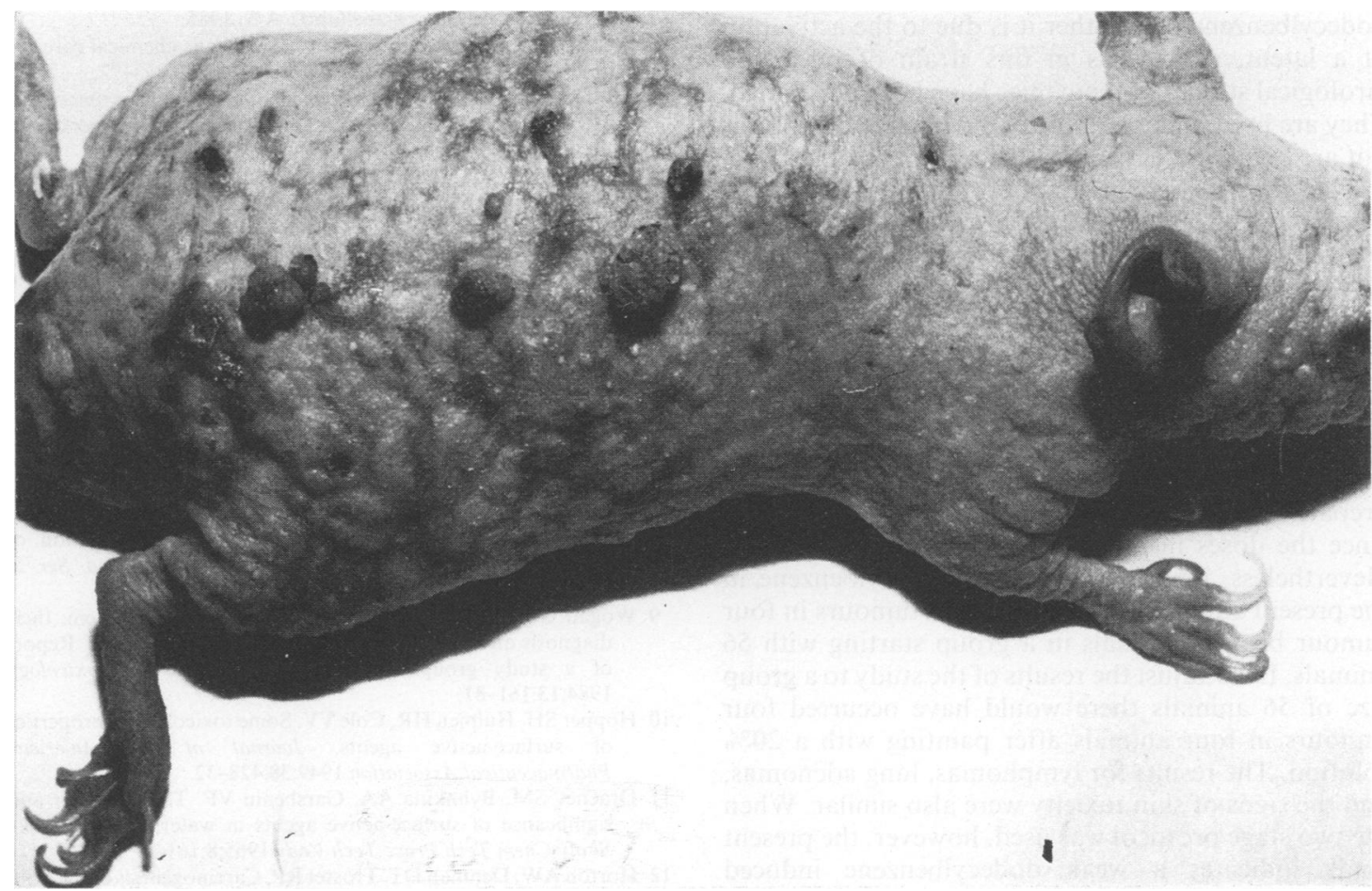

Fig 4 Photograph of a mouse belonging to group 6 with moderate pigment changes, scarring, and many tumours.

and the latency time is much longer.

The present paper shows that dodecylbenzene in the doses used may be weakly tumorigenic, but not carcinogenic, for hairless mice skin, but it only weakly enhances DMBA initiated tumorigenesis and carcinogenesis. Dodecylbenzene is without doubt a skin irritant and seems to increase amyloidosis.

It is debatable whether the hyperproliferation and the eczematous inflammatory changes induced by dodecylbenzene may in themselves enhance tumorigenesis, or act synergistically with other carcinogens in the environment. For a long time it was thought that a tissue in rapid proliferation is particularly sensitive to carcinogens, but the situation is obviously more complicated than that. When DNA synthesis and mitosis are inhibited, the tumour yield may increase. ${ }^{1819}$ Possibly this refers only to the transformational stage that causes DNA injury. There is a possibility that critical alterations primarily induced in DNA may be secondarily fixed by a wave of rapid proliferation, and hence one cannot completely exclude that a strong essentially non-carcinogenic hyperplasiogen may act synergistically with small doses of a carcinogen.

Cell injury and cell death, however, may also reduce tumour production by killing transformed cells that could have started a tumour. Tumorigenesis is always a balance between malignant transformation and cellular toxicity. Acquired cellular resistance also occurs. ${ }^{20}$

We found three completely benign small papillomas in two animals in the acetone treated group. This is probably a random observation, since it has not been observed before in our laboratory. The negative control animals, however, were kept in the same room as the DMBA and dodecylbenzene ones. A small skin contamination with the oil in the form of a faint oil mist cannot be completely excluded. Such small papillomas, however, may also be induced by a virus.

Some authors have suggested that tumorigenicity due to dodecylbenzene may be due to contamination with polycyclic aromatic hydrocarbons (PAH). ${ }^{12} 1516$ We did not test the possible PAH content in the dodecylbenzene we used.

One author has previously reported an increase in the incidence of lymphomas in alkylbenzene treated animals. ${ }^{17}$ The small increase in lymphomas seen in the present study may be an effect of dodecylbenzene. It is impossible, however, on the basis of the available information to know whether this is a direct effect of 
dodecylbenzene or whether it is due to the activation of a latent, slow virus in this strain of mice. No virological studies of these mice have been performed. They are bred under specific pathogen free conditions but are known to develop reticuloses in old age. ${ }^{21}$

The few malignant tumours found in internal organs are probably a random occurrence, without any relation to the treatment with dodecylbenzene or DMBA.

With twice weekly paintings with $50 \mu$ l of a carefully prepared concentration of dodecylbenzene, any possible small mis-dosing of animals is of no significance for the overall results.

In another study a dodecylbenzene called alkylbenzene $\mathrm{C}$ was tested in our laboratory $(\mathrm{O} \mathrm{H}$ Iversen, in preparation). The two results are not easy to compare, since the doses in the two studies were not similar. Nevertheless, painting with $16 \%$ dodecylbenzene in the present study provoked four skin tumours in four tumour bearing animals in a group starting with 56 animals. If we adjust the results of the study to a group size of 56 animals there would have occurred four tumours in four animals after painting with a $20 \%$ solution. The results for lymphomas, lung adenomas, and the signs of skin toxicity were also similar. When the two stage protocol was used, however, the present study indicates a weak dodecylbenzene induced enhancement of DMBA induced tumorigenesis (a slight additive effect), whereas the other study resulted in a slight reduction in DMBA induced tumorigenesis. Probably the two dodecylbenzenes were somewhat different, possibly due to varying contamination with PAH, as mentioned above. The dodecylbenzene alkylbenzene $\mathrm{C}$ may have been more toxic to the skin and hence killed more DMBA transformed cells.

Two students Marit Berg and Inge Engeland carried out the skin paintings, the observations and recordings of tumours and lesions, and the necropsies on the animals with great skill and application. Nigel $\mathbf{J}$ Sarginson from Exxon Chemical International Inc helped in planning and control. I thank the technical staff at the institute for making all the histological sections and the secretariat for typing and retyping the manuscript. The study was supported by Exxon Chemical International Inc, Belgium, without any restrictions on the research programme or the publication of the results.

\section{References}

1 Rönneberg A. Health effects of insulation fluids. Report II. Toxicological properties of alkylbenzenes. Monograph. Oslo:
Standard Telefon og Kabelfabrik A/S, 1985.

2 Iversen $\mathrm{OH}$. Hairless mouse skin in two-stage chemical carcinogenesis. Virchows Arch (Cell Pathol) 1982;38:263-72.

3 Turusov VS, ed. Pathology of tumours in laboratory animals. Vol II: Tumours of the mouse. Lyon: International Agency for Research on Cancer, 1979.

4 Peto R, Pike MC, Day NE, et al. Annex: Guidelines for simple, sensitive significance tests for carcinogenic effects in long-term animal experiments. In: Montesano R, Bertsch $H$, Tomatis $L$, eds. Long-term and short-term screening assays for carcinogens: a critical appraisal. Lyon: International Agency for Research on Cancer, monographs, Suppl 2, 1980:311-426.

5 Peto R. Guidelines on the analysis of tumour rates and death rates in experimental animals. Br J Cancer 1974;29:101-5.

6 Gail MH, Santner TJ, Brown CC. An analysis of comparative carcinogenesis experiments based on multiple times to tumor. Biometrics 1980;36:255-66.

7 Fare $\mathbf{G}$. The influence of number of mice in a box on experimental skin tumour production. $B r J$ Cancer 1965;19:871-7.

8 Iversen $\mathrm{OH}$, Iversen $\mathrm{U}$. Is there a diurnal variation in the susceptibility of mouse skin to the tumorigenic action of methylcholanthrene? Acta Pathol Microbiol Scand Ser A 1976;84:406-14.

9 Wogan GN. Tumors of the mouse hematopoietic system: their diagnosis and interpretation in safety evaluation tests. Report of a study group. CRC Critical Reviews in Toxicology 1984;13:161-81.

10 Hopper SH, Hulpieu HR, Cole VV. Some toxicological properties of surface-active agents. Journal of the American Pharmaceutical Association 1949;38:428-32.

11 Drachev SM, Bylinkina AA, Garshenin VF. The character and significance of surface-active agents in water. Sborn Vysoke Skoly Chem Tech Praze Tech Vody 1965;8:161-6.

12 Horton AW, Denman DT, Trosset RP. Carcinogenesis of the skin. II. The accelerating properties of aliphatic and related hydrocarbons. Cancer Res 1957;17:758-66.

13 Horton AW, Van Dreal PA, Bingham EL. Physicochemical mechanisms of acceleration of skin carcinogenesis. In: Montagna W, Dobson RL, eds. Advances in biology of skin. Carcinogenesis 1966;7:165-82.

14 Lankas GR, Bacter CS, Christian RT. Effect of alkane tumorpromoting agents on chemically induced mutagenesis in cultured V 79 Chinese hamster cells. J Toxicol Environ Health 1978;4:37-41.

15 Horton AW, Bingham EL, Burton MJG, Tye R. Carcinogenesis of the skin. III. The contribution of elemental sulfur and of organic sulfur compounds. Cancer Res 1965;25:1759-63.

16 Saffiotti U, Shubik P, Opdyke DL. Carcinogenesis tests on alkylbenzenes and alkylbenzene sulfonates. Toxicol Appl Pharmacol 1962;4:763-9.

17 Tanaka T, Kano-Tanaka K. The effect of cocarcinogen on transplacental carcinogenesis. In: Severi L, ed. Tumours in early life in man and animals. Proceedings of the 6th Quadrennial International Conference on Cancer, Perugia. Perugia: Perugia University Medical School, 1978:963-71.

18 Iversen $\mathrm{OH}$. Hydroxyurea enhances methylnitrosourea skin tumorigenesis when given shortly before, but not after, the carcinogen. Carcinogenesis 1982;3:891-4.

19 Iversen OH. Enhancement of methylnitrosourea skin carcinogenesis by inhibiting cell proliferation with hydroxyurea or skin extracts. Carcinogenesis 1982;3:881-9.

20 Iversen $\mathrm{OH}$, Astrup EG. The paradigm of two-stage carcinogenesis: a critical attitude. Cancer Invest 1984;2:51-60.

21 Laerum OD. Reticulum cell neoplasms in normal and benzene treated hairless mice. Acta Pathol Microbiol Scand Ser A 1973;81:57-60. 